AстA Pó́tica 37•2

julio-diciembre

$2016(127-134)$

\title{
Ileana Diéguez. Cuerpos sin duelo. Iconografía y teatralidad del dolor. Córdoba (Arg.): Ediciones DocumentA/Escénicas, 2013.
}

\author{
TATIANA BUBNOVA \\ t_bubnova@yahoo.com
}

Cuerpos sin duelo. Iconografia y teatralidad del dolor es un libro estupendamente escrito y académicamente riguroso. Al mismo tiempo es un libro abominable. Lo es porque trata de una manera anatómica, al mismo tiempo que inquietante y reflexiva, aquello que todos sabemos que existe, pero no queremos enterarnos. La parábola y la metáfora del avestruz atraviesa de forma tangencial el libro, como diciendo: somos todos unos avestruces. Pero cuidado, miren cómo se mata a un avestruz: se le tapa la cabeza, se le encobija y se le golpea. Después se le hace filetes.

La cuestión de la estética y del arte actual también es una línea magistral de este libro, problema que se replantea de una manera radical como, por ejemplo, se lo había permitido a sí mismo Roberto Bolaño:

\begin{abstract}
Ya ni los farmacéuticos ilustrados se atreven con las grandes obras, imperfectas, torrenciales, las que abren camino en lo desconocido. Escogen ejercicios perfectos de los grandes maestros. O lo que es lo mismo: quieren ver a los grandes maestros en sesiones de esgrima de entrenamiento, pero no quieren saber nada de los combates de verdad, en donde los grandes maestros luchan contra aquello, ese aquello que nos atemoriza a todos, ese aquello que acoquina y encacha, y hay sangre y heridas mortales y fetidez (289-290).
\end{abstract}

En mi opinión, el arte y en particular el arte literario debe mover y perturbar: la literatura existe para tener la posibilidad de vivenciar una experiencia negativa mediante el texto, y no necesariamente en su propio pellejo. 
Una literatura liviana y complaciente no hará nuestra vida más fácil. La literatura debería ser grave y terrible, para sustituir la experiencia práctica de la vida. Creo que a esto se refiere Bolaño. Sé qué se me puede objetar, pero éste no es el lugar para réplicas y contrarréplicas.

El libro de Ileana Diéguez trata de las formas actuales de arte representativo, como happening, performance, instalación, y de fenómenos limítrofes, de generación espontánea, no propiamente artísticos $-\mathrm{o}$ con intenciones de serlo-, pero que tienen que ver con la estética de una manera perturbadora y desafiante. Trata de aquellas formas que buscan despertar inquietud y de "agitar conciencias", hacer reaccionar al espectador, hacerlo participar en el acto a través de lo emocional y vivencial. Videos, fotografías, instalaciones de todo tipo se distinguen unos de otros por su carácter permanente o instantáneo y perecedero: la variedad es muy grande, pero los une el estar dedicados al dolor humano, intentando romper las acostumbradas fronteras entre la estética y la vida. La estética en este caso no nos remite a la idea tradicional de la belleza, sino a la creación de objetos de todo tipo a los que se les atribuye un sentido reivindicador y emotivo de humanidad, dignidad, compasión, indignación, de agitar conciencias.

Mediante una aproximación seria, teórica y filosófica, que actualiza el pensamiento de los intelectuales del siglo xx más destacados, Ileana Dié- guez logra dignificar tanto el fenómeno formal de estos objetos - no me atrevo a emplear el concepto de género artístico en este caso- como de los creadores y de la triste humanidad carnal y despreciada, objeto de su esfuerzo formal, incitadores del acto creador.

Diéguez señala la nueva dimensión de lo estético: "De manera general, los artistas que producen sus obras en torno a la memoria de traumas sociales, desarrollan sus prácticas como procesos de investigación en los que ellos mismos quedan expuestos afectiva y síquicamente" (224). Hay que agregar que los artistas de la memoria cuentan con la participación vivencial y activa del receptor/espectador.

Se trata de hablar del cuerpo, el cuerpo que sufre, pero no un cuerpo abstracto o inscrito como símbolo en un contexto teológico y/o artístico, sino aquel que está aquí y ahora, que sufre y muere, y es profanado y desintegrado para transmitir un mensaje, que nada tiene que ver con el arte o la estética entendida tradicionalmente. Un cuerpo que está destinado a infundir miedo, a marcar un territorio de poder, para anunciar la cancelación de todo convencionalismo de conductas y recursos en el tratamiento de la persona: ése es el objeto de la reflexión, la estética peculiar de la muerte a que está sometido el ser humano. También es un balance del estado de las cosas (de "la vertiginosa decadencia de los valores", 248) en el que estamos sumergidos y del que, quiérase o no, somos participantes. 
Plantear esta dimensión del fenómeno sería señalar la existencia de la responsabilidad personal en el "acontecimiento del ser", en el cual -ontológicamente - no hay coartada (cfr. Bajtín). No queda otra cosa sino apelar a la "metafísica de la presencia" para implicar al ser humano en una responsabilidad ontológica. La responsabilidad colectiva, que desde luego existe, es difusa y propensa a desaparecer una vez que el espectador-participante se aleja del escenario público. La responsabilidad imputable, forense, no trata los casos de conciencia. En cambio, el trauma personal del contacto con el horror debería permanecer, se supone, de un modo indeleble en la memoria: tal sería el horizonte de expectativas de la producción de estas formas estéticas.

El psicoanálisis ayuda al sujeto de "mente incompleta" exonerándolo de la culpa. El arte contemporáneo la está explicitando más allá de los juegos con el inconsciente. El propósito es ir más allá de las formas y géneros desgastados, que llegaron a ser, a menudo, tan sólo palabras e imágenes que están siendo sobrepasados por otras palabras e imágenes de la realidad.

Así, la literatura clásica rusa (siglos XIX-XX, Dostoievski, Tólstoi, Andréiev, o Varlam Shalámov en el período soviético), y el arte (Goya, Munch, Francis Bacon o Käthe Köllwitz, por mencionar a algunos) han incursionado en estos terrenos. (No pretendo, ni remotamente, proponer una lista exhaustiva).
Dostoievski lo trata de señalar evocando a la conciencia cristiana: "cada uno de nosotros es culpable de todo ante todos", "cada persona es culpable ante todos, por todos y por todo". Pero, no es suficiente con volver la vista a Dostoievski: el pobre creía que había límites, que después de masacrar a dos mujeres indefensas con un hacha, la conciencia del asesino no lo dejaría nunca en paz. Ajmátova, la gran poeta del siglo xx, advertía que la conciencia de Dostoievski era una ilusión decimonónica, y que en el siglo xx se podía fusilar a decenas de personas en la madrugada, e ir en la tarde al cine no sin antes regañar a la esposa por un peinado cursi (por decir algo; hemos presenciado, y al por mayor, casos mucho más terribles).

La misma Ajmátova, ante el espectáculo del desastre de su país del que es testigo, acepta ser participante: “¿Cómo pudo haber sucedido que culpable de todo sea yo?"

En la película de Andrei Tarkovski, El espejo (1974), la cuestión de la no coartada en el ser se plantea como voluntad para la muerte (propia). ¿Por qué una vez que uno se enferma, se niega a levantarse? Por sentir la culpa de aquello que alguna vez hayamos hecho o dejado de hacer, y no nos podemos perdonar a nosotros mismos. La enfermedad del alma no se produce como ligada al pecado original, como quiere la tradición judeo-cristiana, sino por la culpa generada a partir de una relación distorsionada con otras personas, por la conciencia del mal de 
vivir que nos agobia. Pero el plano cotidiano en que lo sitúa el cineasta hace perder de vista la dimensión masiva del mal, de la que, por lo demás, está más que enterado: nuestro tiempo es un "tiempo de grandes muertes al por mayor" (Mandelstam) causadas también por fuerzas suprapersonales.

Pero una cosa es decirlo y concientizarlo, y muy otra es enfrentarnos al cuerpo masacrado. La literatura latinoamericana también aborda estas cuestiones y las enuncia: "Aunque debo admitir que no es lo mismo estar incompleto de la mente por haber sufrido descuartizamiento de los propios hijos que por haber descuartizado hijos ajenos [...], la totalidad de los habitantes de este país no [está] completa de la mente" (Castellanos:14).

Nos hemos acostumbrado e insensibilizado respecto de una situación intolerable que se ha vuelto cotidiana: una locutora de la TV con una voz sedante e incluso alegre anuncia el saldo diario de las muertes violentas. Ha sido formulada la descomposición del tejido social... Del que por desgracia formamos parte.

Los "señores de la muerte" y el "Señor Matanza". ¿Quién no recuerda a la "Mano Negra", al astroso y desparpajado Manuchau? El rock nos grita las verdades: "i¡Esta sociedad es la propiedad del Señor Matanza!! Él decide lo que va, dice lo que no será / decide quién la paga dice quien vivirá".

Hay quienes tratan de especificar el origen y la peculiaridad del mal en el territorio latinoamericano, aunque el mal es universal y omnipresente:

En el contexto post-colonial, la fisura que separa la obra de su origen (la realidad vivida) nunca se cierra, y su existencia es tan notoria que a menudo termina siendo el tema universal. En esto se apoya la explicación del hecho de que todos los conceptos esenciales de la crítica cultural latinoamericana subrayen, con diferentes entonaciones, el yo escindido de la cultura latinoamericana como su ineludible condición de posibilidad. ${ }^{1}$

Uno no quiere saber y voltea la cabeza para eludir la siniestra impresión de la muerte cotidiana con el velo de cualquier imagen reconfortante o frívola. ¿Es también esta dualidad resultado de una conciencia escindida? Mejor no saber, y aun mejor no pensar. Y, finalmente, ¿quién tiene la culpa? Ciertamente, nosotros no. Y, sobre todo, ¿qué hacer? Las dos preguntas sacramentales de la literatura rusa ${ }^{2}$ siguen siendo actuales, y los

1 "In a post-colonial context, the fissure that separates work from origin [lived reality] is never closed, and its existence is so notorious that often ends up as the subject of the world. Here lies the explanation for the fact that all essential concepts of Latin American cultural criticism [...] underline, with different intonations, the fissured self of Latin American culture as its ineluctable condition of possibility" (Legrás 2008; trad. mía).

${ }^{2}$ ¿Quién tiene la culpa? (1847), de Herzen, y ¿Qué hacer? (1865), de Chernyshevski. 
intentos de materializar las respuestas tomadas como recetas han sido desastres o fracasos históricos: la Unión Soviética, Cuba, Kampuchea...

Como decía Mafalda, el sabio personaje de Quino, sobre el estado del tiempo: la culpa la tiene el gobierno. Los feminicidios de Ciudad Juárez han sido muy anteriores al gobierno de Felipe Calderón o de Peña Nieto, pero sellamos nuestros desastres con la fecha de hoy: "...la guerra que hace más de seis años que vivimos", se dice en 2013. No se vale ponerle la fecha al dolor, ni actualizarlo al último día, porque al día siguiente llega otra noticia de una atrocidad más. Al dirigir una plegaria a un cielo vacío, uno se acuerda de la interpretación del Ángel de la Historia de Paul Klee, que había hecho Walter Benjamin: adelante, el horror del futuro, atrás, el desastre, las ruinas humeantes causadas por la barbarie.

¿Se trata de un arte de denuncia una vez más? Dice Ileana Diéguez: "[...] callar la barbarie sería precisamente otorgar la Victoria a los perpetradores de la barbarie" (45). Los que somos estudiosos de la literatura latinoamericana recordamos el caso de José Eustasio Rivera, que en un solo libro - La Vorágine - quiso incluir la ficción personal cuya clave fue la Violencia (que, por cierto, ha resultado emblemática y profética de su país) y la denuncia de la condición de los caucheros en la selva amazónica: nadie le quiso creer (cfr. Neale Silva).
Pero el panteón de los restos de los cadáveres pescados por la población del río Magdalena, nombrados y enterrados provisionalmente, son dotados, por la fe religiosa e ingenua, de la cualidad de santos milagreros, capaces de cumplir los deseos si se les hace la promesa de un entierro posterior. Una "instalación" espontánea de esta índole, realizada con una inspiración estética existencial, revela la necesidad de fijar la memoria, de pagar la culpa universal de todos, de devolverle el respeto a la muerte, de una responsabilidad instintiva que muchos hemos perdido. El morbo de ver las famosas cobijas que cubren los cadáveres de los ajusticiados, integradas a la imagen de Cristo, tal vez se amortigüe por un brote de la conciencia de esta virtual participación en el desastre.

Tal vez, no hay que evocar tanto la responsabilidad colectiva, que a la postre resulta abstracta, sino accionar una responsabilidad personal y arraigada en la estructura emotiva, racional y moral de cada quien. No hay que dividir la humanidad, de una manera maniquea, en dos partes: unos somos buenos e incapaces de matar una mosca, y otros son malos, quién sabe de dónde salieron. Las preguntas de este tipo se hacía a sí mismo Miguel de Unamuno, el gran agitador de las conciencias españolas, del cual, dicen, hoy en día no quedan sino textos: literatura, en fin.

Nadie sabe si los malos nacen malos o se hacen, como se ha repetido muchas veces, pero lo que somos 
nosotros, a nosotros ningún destino, ninguna fatalidad, ninguna contingencia nos llevaría a degollar cadáveres, como lo hacía aquel desgraciado "Ponchis", de catorce años, el niño decapitador del crimen organizado. Nosotros somos diferentes. Cuando decimos "pueblo", ¿a quién nos referimos? Nosotros mismos, ¿somos o no pueblo? Esto, sin duda, se elige de acuerdo con las conveniencias: hoy sí, mañana tal vez no. En esto también se desdibujan los límites.

Si nos hacemos cargo del dolor ajeno, hagámonos cargo de la responsabilidad "ajena”, porque es también la nuestra. Pero nadie está dispuesto a decir: yo también tengo la culpa de que la barbarie exista.

Es difícil separar, en el libro de Ileana Diéguez, el impacto de la materia tratada de su análisis conceptual: uno se siente como en un teatro anatómico, del que se puede salir en cualquier momento cerrando el libro, y cancelar de un golpe la "participación" y la "responsabilidad". Normalmente nos resulta imposible diferir las sensaciones materiales del asco y del horror de un fastidio intelectual rayano en la impotencia. La solidaridad exige la presencia de cuerpo presente.

En el libro de Ileana Diéguez la parte puramente estética se analiza de acuerdo con los conceptos de Walter Benjamin: luto, alegoría, constelación, etc. Podemos replicar que el arte, que ha perdido el aura que le solía conferir un estatus sacro, está regresando al concepto de lo sagrado confiriéndo- le una dignidad religiosa a los restos anónimos rescatados de los ríos de la cuenca amazónica, haciendo luto por aquellos que lo habían perdido todo, no sólo la vida sino incluso el nombre y, con él, el derecho a ser recordados, la rememoración que permite la exhibición del cuerpo. Pero... ¿Qué tan seguros estamos de que únicamente se trata de las víctimas pasivas del "proceso"? En el estado presente de las cosas es lo que menos importa, porque todos somos a la vez víctimas y victimarios.

Recursos y datos de historia, antropología, etnología, filosofía, teoría crítica y teoría literaria, estética y, sobre todo, de la reflexión ética, atraviesan y dan forma al material que reúne este libro, trabajado de una manera interdisciplinaria, que evoca el arte del performance y de la instalación, la pintura, la fotografía y el teatro. Ileana Diéguez no es novata en el campo, se ha ocupado desde hace tiempo de estas formas liminares que apelan a la realidad del hecho simbolizándolo en diferente grado: tiene en su haber varios libros y estudios anteriores. Desde hace tiempo se esfuerza por desbrozar el terreno teórico de la relación entre los fenómenos éticos y el arte.

La cercanía a la realidad y el carácter perecedero, instantáneo de la mayoría de estas exposiciones artísticas ponen en cuestión su naturaleza estética, por lo de que ars longa, vita brevis est. El arte de la memoria siempre se ha practicado por las letras, pero éstas actualmente son duramente atacadas, 
en su misión de la transmisión del conocimiento y de la memoria, por la visualidad comercial del cine y la televisión, por la permanente agresión de la industria de la diversión. De modo que los modelos literarios más genuinos quedan relegados por difíciles y serios, y también porque hacen pensar, mientras que el objetivo de la fabricación de los productos de diversión es totalmente opuesto. Absorbidos por este vórtice ensordecedor y enajenante, nos dejamos llevar lejos de aquella realidad en la que el cuerpo humano pierde toda dignidad y está siendo usado para necesidades y gustos inconfesables, se sacrifica como algo que estorba, se quita del camino con un gesto fácil. Pero esta lejanía, subraya Diéguez, es sólo virtual e ilusoria.

Todas estas cosas, y más, surgen al leer el inquietante - y brillantelibro de Ileana Diéguez. Esperemos que no quede como el registro de un momento histórico, sino que perdure mediante las letras que documentan y registran, y al mismo tiempo invitan al duelo, a la reflexión y, con suerte, a la acción.

BIBLIOGRAFÍA

Bolaño, Roberto. 2666. Barcelona: Anagrama, 2004.

Castellanos Moya, Horacio. Insensatez. México: Tusquets, 2004.

Legrás, Horacio. Literature and Subjection: The Economy of Writing and Marginality in Latin America. Pittsburgh: University of Pittsburgh Press, 2008.

Neale Silva, Eduardo. El horizonte humano. México: Fondo de Cultura Económica, 1960. 
TATiana Bubnova

Egresada de El Colegio de México con la Tesis Doctoral "El 'Retrato de la Lozana andaluza' de Francisco Delicado a la luz de las teorías de M. Bajtín". Traductora de las obras de Bajtín al español: Problemas de la poética de Dostoievski (1986); Hacia una filosofía del acto ético. De los borradores y otros escritos (1997) y Estética de la creación verbal (2003), entre otros. Autora de numerosos textos que tratan de integrar las ideas bajtinianas en el análisis de los textos hispánicos y en el comparativismo, entre los que destacan: F. Delicado puesto en diálogo (1987) y Entre poética, retórica y prosaica: De la teoría literaria al diálogo entre culturas (2002). Investigadora del Instituto de Investigaciones Filológicas desde inicios de 1979. Imparte las clases de Teoría Literaria y Literatura Comparada en el posgrado de la Facultad de Filosofía y Letras de la UNAM. 